\title{
Effects of cola on the rats' urine proteome
}

\begin{abstract}
The nature of biomarker is change. Contrast to the blood which is under homeostatic controls, urine reflects changes in the body earlier and more sensitive therefore is a better biomarker source. However, the urinary proteome is affected by many factors such as diet, medication, daily activities. We studied the effect of cola intake on urinary proteome, using animal models to minimize related factors. Urine samples before and after cola treatment were collected and analyzed by SDS-PAGE and LCMS/MS. Spectral counts was used to perform semi-quantitative analysis. In total, 371 proteins were identified with $\mathrm{FDR}<1 \%$ and at least 2 peptides. To be conservative, all of the differential proteins met the following criteria: 1); T-test values $\mathrm{P}<0.05$, 2) the variation trend in all three animals was consistent, and the fold change was at least 1.5 in each rat. Twelve proteins significantly changed after cola intake, including 4 increased and 8 decreased. Six significantly changed proteins were previously annotated as urinary candidate biomarkers. Cola is a common beverage around the world; thus, this differential protein should be considered for future diseases biomarker studies.
\end{abstract}

Volume 4 Issue 3 - 2016

\author{
Kunyu Tang, Weiwei Qin, Ting Wang, Youhe \\ Gao \\ College of Life Science, Beijing Normal University, China \\ "both authors have equal contribution
}

\begin{abstract}
Correspondence: Youhe Gao, Department of Biochemistry and Molecular Biology, Beijing Normal University, Gene Engineering and Biotechnology Beijing Key Laboratory, Beijing, 100875, P. R. of China, Tel +86 I0 58804382,

Email gaoyouhe@bnu.edu.cn
\end{abstract}

Received: October 31, 2016 | Published: November 07, 2016

Keywords: cola, biomarker, urinary proteome

\section{Introduction}

Biomarkers are the measurable changes associated with physiological or pathophysiological process, and the most fundamental property of biomarkers is change. ${ }^{1}$ Blood is under the control of homeostasis to remain stable and balanced for protecting organs from disturbing factors, so it tends to remove changes quickly. Urine, as a filtrate of blood, without homeostatic controls, can accumulate all kinds of changes so it is a better source for biomarker discovery than blood. ${ }^{1,2}$ So far, a wide range of candidate urinary biomarkers have been reported. ${ }^{3}$

However, urinary biomarkers research can be challenging for the fact that changes in urine are very complicated. There are various elements affecting urinary proteome, diet, medication, gender, age, daily rhythms, exercise, and hormone status. ${ }^{4}$ It is difficult to determine whether potential biomarkers are truly related to diseases. We tried to use rats to study their effects one factor at a time. The results can help to annotate the potential disease biomarkers that are affected by these confounding factors.

Cola is a very common beverage in our daily life. The purpose of our experiment is to find out whether drinking cola will cause changes on urinary proteome and determine which proteins are affected.

\section{Materials and methods}

\section{Ethics statement and cola treatment}

Four adult male Wistar rats $(210-220 \mathrm{~g})$ were purchased from Charles River, China. All animals were kept with standard laboratory diet under controlled indoor temperature $\left(22 \pm 1^{\circ} \mathrm{C}\right)$ and humidity (65\%-70\%). The experiment was approved by Institutional Animal Care Use \& Welfare Committee of Institute of Basic Medical Sciences, Peking Union Medical College (Animal Welfare Assurance Number: ACUC-A02-2013-015). For these 4 rats, all drinking water was replaced with cola (commercially available sucrose-sweetened carbonated drink, Coca-Cola ${ }^{\mathrm{TM}}$, China). Before the cola treatment and at the fourth day after cola treatment, all rats were individually placed in the metabolic cages for 12 hours. Then the twelve-hour urine samples were used for proteomics analysis.

\section{Urinary proteins extraction and tryptic digestion}

Urine was centrifuged at $3500 \mathrm{~g}$ for $30 \mathrm{~min}$ immediately after collection. Three volumes of ethanol were added after removing the pellets, and the samples were precipitated at $4^{\circ} \mathrm{C}$. Then, $8 \mathrm{M}$ urea, $2 \mathrm{M}$ thiourea, $25 \mathrm{~mm}$ dithiothreitol and $50 \mathrm{~mm}$ Tris were used to re-dissolve the pellets. The protein concentration of each sample was measured by the Bradford protein assay. A filter-aided sample preparation $\operatorname{method}^{5}$ was used to digest the proteins in the three samples (each contained $200 \mu \mathrm{g}$ of urinary protein). Briefly, protein solution was reduced with $4.5 \mathrm{~mm}$ DTT for $1 \mathrm{~h}$ at $37^{\circ} \mathrm{C}$, and then alkylated with $10 \mathrm{~mm}$ IAA for $30 \mathrm{~min}$ at room temperature in darkness. Finally, proteins were digested with trypsin $(1 \mu \mathrm{g} / 50 \mu \mathrm{g}$ protein) overnight at $37^{\circ} \mathrm{C}$. The resulting peptides were desalted and then lyophilized for LC-MS/MS analysis.

\section{LC-MS/MS analysis}

The digested peptides were dissolved in $0.1 \%$ formic acid and loaded on a trap column $(75 \mu \mathrm{m} \times 2 \mathrm{~cm}, 3 \mu \mathrm{m}, \mathrm{C} 18,100 \AA)$. The eluent was transferred to a reversed-phase analytical column $(50 \mu \mathrm{m} \times 150 \mathrm{~mm}$, $2 \mu \mathrm{m}, \mathrm{C} 18,100 \AA)$ by Thermo EASY-nLC 1200 HPLC system. Peptides were analyzed by Fusion Lumos mass spectrometer (Thermo Fisher Scientific). The Fusion Lumos was operated on data-dependent acquisition mode. Survey MS scans were acquired in the Orbitrap using a $350-1550 \mathrm{~m} / \mathrm{z}$ range with the resolution set to 120,000 . The most intense ions per survey scan (top speed mode) were selected for collision-induced dissociation fragmentation, and the resulting fragments were analyzed in the Orbitrap. Dynamic exclusion was employed with a 30 s window. Three technical replicate analyses were performed for each sample.

\section{Protein identification and statistical analysis}

The MS/MS data were processed using Mascot software (version 2.4.1, Matrix Science, London, UK) and searched against the Swiss- 
Prot rat database (05/03/2013; containing 9,354 sequences). Search parameters were set as follows: $10 \mathrm{ppm}$ precursor mass tolerance, $0.02 \mathrm{Da}$ fragment mass tolerance, two missed cleavage sites allowed in the trypsin digestion, cysteine carbamidomethylation as fixed modification, oxidation (M) as variable modifications. The Mascot results were filtered and validated by Scaffold (version 4.0.1, Proteome Software Inc., Portland, OR, USA). Peptide identifications were accepted if they were detected with $90.0 \%$ probability and an FDR less than $0.1 \%$ by the Scaffold local FDR algorithm. Protein identifications were accepted if they were detected with FDR less than $1 \%$ and contained at least 2 identified peptides. Spectral counting was used to compare protein abundance between different experimental groups. To be conservative, all of the differential proteins met the following criteria: 1); T-test values $\mathrm{P}<0.05,2$ ) the variation trend in all three animals was consistent, and the fold change was at least 1.5 in each rat.

\section{Results and discussion}

\section{SDS-PAGE analysis of urinary proteins before and} after cola treatment

$25 \mu \mathrm{g}$ urinary proteins were separated using $12 \%$ SDS-PAGE gel. There were consistent changes before and after cola treatment. As is shown in Figure 1, during 55-100kDa and $130-180 \mathrm{kDa}$, the bands are lighter after drinking cola, while about $15 \mathrm{kDa}$, the bands are darker, indicating that drinking cola will have an obvious impact on the rat's urinary proteome (Figure 1).

\section{Urine proteome changes identified by LC-MS/MS}

To investigate the effects of cola intake on the urinary proteome, the urinary proteomes from three rats before and after cola intake were analyzed by LC-MS/MS. Six samples three rats (three samples from cola treatment before, and three after treatment) were analyzed by UPLC coupled with Fusion Lumos. In total, 371 proteins were

Table I Details of changed urinary proteins before and after drinking cola identified with $\mathrm{FDR}<1 \%$ and at least 2 peptides (Supporting Information Tables S1). For the total difference in spectra after the cola treatment, spectral counting was used to perform semiquantitative analysis. The details of criteria are described in Materials and methods.

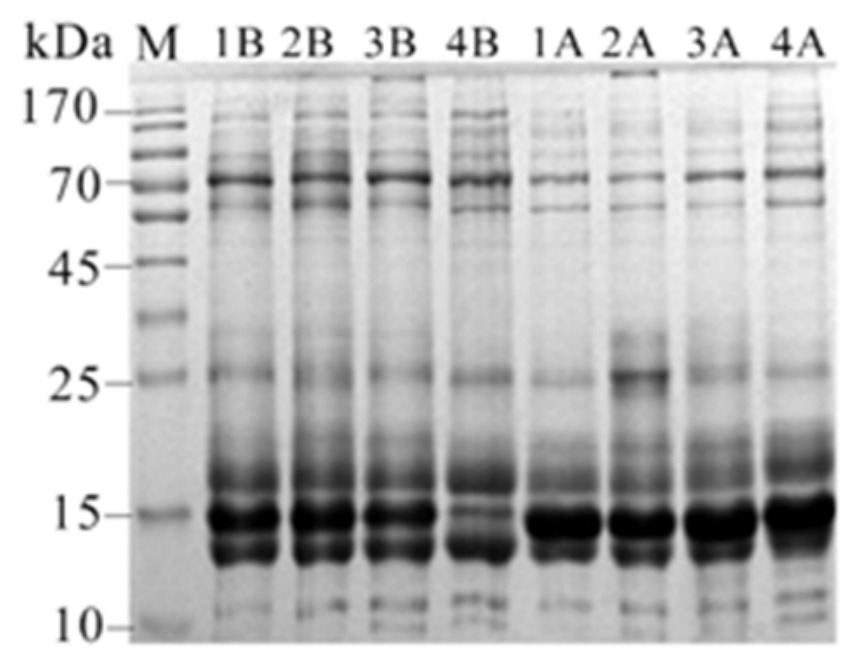

Figure I SDS-PAGE analysis of the urinary protein samples before and after cola treatment. (M, protein marker; $B$, before cola treatment; $A$, after cola treatment).

Twelve proteins were significantly altered after cola intake (Table 1). Four proteins increased and 8 decreased, 9 proteins have human orthologs. All significant changed proteins were searched against the Urinary Protein Biomarker Database. ${ }^{3}$ Six significantly changed proteins were previously annotated as urinary candidate biomarkers (Table 1). Cola is a common beverage around the world; thus, these protein changes should be considered when researching diseases biomarkers.

\begin{tabular}{|c|c|c|c|c|c|c|c|c|c|c|c|c|c|c|}
\hline \multirow[t]{2}{*}{ ID } & \multirow{2}{*}{ Protein name } & \multirow{2}{*}{$\begin{array}{l}\text { MW } \\
(\mathrm{kDa})\end{array}$} & \multicolumn{3}{|c|}{$\begin{array}{l}\text { PSM } \\
\text { (Before) }\end{array}$} & \multicolumn{3}{|c|}{$\begin{array}{l}\text { PSM } \\
\text { (After) }\end{array}$} & \multicolumn{3}{|c|}{ Fold change } & \multirow[t]{2}{*}{$\begin{array}{l}\text { Change } \\
\text { tendency }\end{array}$} & \multirow[t]{2}{*}{$\begin{array}{l}\text { Human } \\
\text { ortholog }\end{array}$} & \multirow[t]{2}{*}{ Diseases } \\
\hline & & & I & 2 & 31 & 1 & 2 & 3 & Ratl & Rat2 & Rat3 & & & \\
\hline P20759 & Ig gamma-I chain $C$ region & 36 & 0 & 2 & 35 & 5 & 6 & 7 & $\infty$ & 3 & 2.3 & UP & NO & None \\
\hline P02625 & Parvalbumin alpha & 12 & 0 & 1 & 02 & 2 & 2 & 3 & $\infty$ & 2 & $\infty$ & UP & P20472 & Compound-induced skeletal muscle toxicity ${ }^{6}$ \\
\hline P42854 & $\begin{array}{l}\text { Regenerating islet-derived } \\
\text { protein 3-gamma }\end{array}$ & 19 & 13 & 15 & 164 & 49 & 87 & 53 & 3.8 & 5.8 & 3.3 & UP & NO & Membranous nephropathy ${ }^{7}$ \\
\hline P27590 & Uromodulin & 71 & 77 & 74 & 631 & 149 & 140 & 164 & 1.9 & 1.9 & 2.6 & UP & P079II & $\begin{array}{l}\text { Sepsis-induced acute renal failure }{ }^{8} \\
\text { Focal segmental glomerulosclerosis and } \\
\text { mesangioproliferative glomerulonephritis } \\
\text { Preeclampsia }^{10}\end{array}$ \\
\hline P07897 & Aggrecan core protein & 221 & 3 & 6 & 42 & 2 & 1 & I & 0.7 & 0.2 & 0.3 & DOWN & NO & None \\
\hline 035112 & CDI66 antigen & 65 & 3 & 4 & 32 & 2 & 1 & 2 & 0.7 & 0.3 & 0.7 & DOWN & Q13740 & Type I diabetes" \\
\hline P42I23 & $\begin{array}{l}\text { L-lactate dehydrogenase } \\
\text { B chain }\end{array}$ & 37 & 5 & 4 & 63 & 3 & I & 2 & 0.6 & 0.3 & 0.3 & DOWN & P07। 95 & None \\
\hline POI026 & Complement C3 & 186 & 14 & 10 & 177 & 7 & 3 & 8 & 0.5 & 0.3 & 0.5 & DOWN & P0I024 & None \\
\hline P07I50 & Annexin Al & 39 & 4 & 7 & 52 & 2 & 1 & I & 0.5 & 0.1 & 0.2 & DOWN & P04083 & $\begin{array}{l}\text { Glomerular injury'12 } \\
\text { Interstitial fibrosis }{ }^{13} \\
\text { HER2 breast cancer }{ }^{14}\end{array}$ \\
\hline P50399 & $\begin{array}{l}\text { Rab GDP dissociation } \\
\text { inhibitor beta }\end{array}$ & 51 & 4 & 4 & 32 & 2 & 2 & 2 & 0.5 & 0.5 & 0.7 & DOWN & P50395 & None \\
\hline
\end{tabular}


Table Continued.

\begin{tabular}{|c|c|c|c|c|c|c|c|c|c|c|c|c|c|c|}
\hline \multirow{2}{*}{ ID } & \multirow{2}{*}{ Protein name } & \multirow{2}{*}{$\begin{array}{l}\text { MW } \\
(\mathrm{kDa})\end{array}$} & \multicolumn{3}{|c|}{$\begin{array}{l}\text { PSM } \\
\text { (Before) }\end{array}$} & \multicolumn{3}{|c|}{$\begin{array}{l}\text { PSM } \\
\text { (After) }\end{array}$} & \multicolumn{3}{|c|}{ Fold change } & \multirow[t]{2}{*}{$\begin{array}{l}\text { Change } \\
\text { tendency }\end{array}$} & \multirow[t]{2}{*}{$\begin{array}{l}\text { Human } \\
\text { ortholog }\end{array}$} & \multirow[t]{2}{*}{ Diseases } \\
\hline & & & 1 & 2 & 3 & 1 & 2 & 3 & Rat I & Rat2 & Rat3 & & & \\
\hline B5DFC9 & Nidogen-2 & 153 & 3 & 4 & 4 & I & I & 2 & 0.3 & 0.3 & 0.5 & DOWN & Q14II2 & None \\
\hline Q9נJ40 & $\begin{array}{l}\mathrm{Na}(+) / \mathrm{H}(+) \text { exchange } \\
\text { regulatory cofactor } \mathrm{NHE}- \\
\mathrm{RF} 3\end{array}$ & 57 & 13 & 12 & 15 & 4 & 7 & 8 & 0.3 & 0.6 & 0.7 & DOWN & Q5T2WI & $\begin{array}{l}\text { Protein excretion with Sodium loading }{ }^{15} \\
\text { Aldosteronism }{ }^{16}\end{array}$ \\
\hline
\end{tabular}

\section{Acknowledgements}

Thanks to the Australian Proteome Analysis Facility (APAF) for funding this research.

\section{Conflict of interest}

The author declares no conflict of interest.

\section{References}

1. Gao Y. Urine-an untapped goldmine for biomarker discovery? Sci China Life Sci. 2013;56(12):1145-1146.

2. Li M, Zhao M, Gao Y. Changes of proteins induced by anticoagulants can be more sensitively detected in urine than in plasma. Sci China Life Sci. 2014;57(7):649-656.

3. Shao C, Li M, Li X. A Tool for Biomarker Discovery in the Urinary Proteome: A Manually Curated Human and Animal Urine Protein Biomarker Database. Mol Cell Proteomics. 2011;10(11):M111.010975.

4. Wu J, Gao Y. Physiological conditions can be reflected in human urine proteome and metabolome. Expert Rev Proteomics. 2016;12(6):623-636.

5. Wisniewski JR, Zougman A, Nagaraj $\mathrm{N}$, et al. Universal sample preparation method for proteome analysis. Nat Methods. 2009;6(5):359362

6. Dare TO, Davies HA, Turton JA, et al. Application of surface-enhanced laser desorption ionization technology to the detection and identification of urinary arvalbumin- $\alpha$ : A biomarker of compound-induced skeletal muscle toxicity in the rat. Electrophoresis. 2002;23(18):3241-3251.

7. Ngai HH, Sit WH, Jiang PP, et al. Serial Changes in urinary proteome profile of membranous nephropathy: implications for pathophysiology and biomarker Discovery. J Proteome Res. 2006;5(11):3038-3047.
8. Holly MK, Dear JW, Hu XZ, et al. Biomarker and Drug Target Discovery Using Proteomics in a New Rat Model of Sepsis-Induced Acute Renal Failure. Kidney Int. 2006;70(3):496-506.

9. Wang Y, Chen Y, Zhang Y, et al. Differential ConA-enriched urinary proteome in rat experimental glomerular diseases. Biochem Biophys Res Commun. 2008;371(3):385-390.

10. Kononikhin AS, Starodubtseva NL, Bugrova AE, et al. An untargeted approach for the analysis of the urine peptidome of women with preeclampsia. J Proteomics. 2016;149:38-43.

11. Suh MJ, Tovchigrechko A, Thovarai V, et al. Quantitative Differences in the Urinary Proteome of Siblings Discordant for Type 1 Diabetes Include Lysosomal Enzymes. J Proteome Res. 2015;14(8):3123-3135.

12. Ka SM, Tsai PY, Chao TK, et al. Urine annexin A1 as an index for glomerular injury in patients. Dis Markers. 2014;2014:854163.

13. Yuan Y, Zhang F, Wu J, et al. Urinary candidate biomarker discovery in a rat unilateral ureteral obstruction model. Sci Rep. 2015;5:9314.

14. Gajbhiye A, Dabhi R, Taunk K, et al. Urinary proteome alterations in HER2 enriched breast cancer revealed by multipronged quantitative proteomics. Proteomics. 2016;16(17):2403-2418.

15. Thongboonkerd V, Klein JB, Pierce WM, et al. Sodium loading changes urinary protein excretion: a proteomic analysis. Am J Physiol Renal Physiol. 2003;284(6):F1155-F1163.

16. van der Lubbe N, Jansen PM, Salih M, et al. The phosphorylated sodium chloride cotransporter in urinary exosomes is superior to prostasin as a marker for aldosteronism. Hypertension. 2012;60(3):741-748. 